Aim of the study: The subject of study was the stability of cisplatin in concentrate in glass vials and diluted in polyethylene $(\mathrm{PE})$ bags stored at $15-25^{\circ} \mathrm{C}$ for up to 30 days.

Material and methods: Original vials of cisplatin injection ( $1 \mathrm{mg} / \mathrm{ml}$, Teva) were stored at room temperature and subjected to re-piercing after $1,2,3,7,14$, 21,28 and 30 days following the initial piercing. Cisplatin infusions at nominal concentrations of $0.1 \mathrm{mg} / \mathrm{ml}$ were pre pared in $0.9 \%$ sodium chloride $(1000 \mathrm{ml})$ in PE bags. Chemical stability was measured by means of a stability-indicating high-performance liquid chromatography (HPLC) assay. Physical stability was assessed by visual inspection in normal light.

Results: The concentration of cisplatin at each sampling time in the analysed solutions remained within $92.0-100.7 \%$ of initial concentration, regardless of the container. No changes in colour or turbidity were observed in any of the vials or prepared solutions.

Conclusions: Cisplatin, both undiluted in glass containers and diluted with $\mathrm{NaCl}$ $0.9 \%$ in PE bags, remains stable $(<10 \%$ degradation) for at least 30 days at room temperature when protected from light.

Key words: cisplatin, stability, concentrate, infusion.

\section{The physical and chemical stability of cisplatin (Teva) in concentrate and diluted in sodium chloride $0.9 \%$}

\author{
Agnieszka Karbownik ${ }^{1}$, Edyta Szałek ${ }^{1}$, Hanna Urjasz ${ }^{1}$, Aleksandra Głęboka ${ }^{2}$, \\ Emilia Mierzwa ${ }^{1}$, Edmund Grześkowiak ${ }^{1}$
}

1Department of the Clinical Pharmacy and Biopharmacy, Poznan University of Medical Sciences, Poznan, Poland

2Pharmacy, Wielkopolska Cancer Centre, Poznan, Poland

\section{Introduction}

Cisplatin (cis-diamminedichloroplatinum, cis-Pt) is a non-organic complex, where the central atom is divalent platinum. The anti-neoplastic activity of the compound is conditioned by the spatial layout of chlorine atoms in cis position. The molecular formula of cisplatin is $\mathrm{Cl} 2 \mathrm{H} 6 \mathrm{~N} 2 \mathrm{Pt}$ (MW 300.05) and the structure is provided in Figure 1. The chemotherapeutic belongs to the group of cycle-specific and phase-non-specific drugs. However, the effects of formation of cross-links with DNA are most marked during the S-phase of the cell cycle. Cisplatin is a potent anti-tumour drug. Cisplatin-based combination chemotherapy regimens are currently used as a front-line therapy in the treatment of testicular cancer, ovarian germ cell tumours, epithelial ovarian cancer, head and neck cancer, advanced cervical cancer, bladder cancer, mesothelioma, endometrial cancer, non-small cell lung cancer, malignant melanoma, carcinoids, penile cancer, adrenocortical carcinoma and carcinoma of unknown primary [1-3]. The anti-cancer activity of cisplatin is partly attributed to the formation of inter- and intra-strand cross links in DNA, which inhibit gene transcription and DNA replication, thereby blocking protein synthesis and cell proliferation [4-6].

Cisplatin must be diluted in sodium chloride infusion. Because of the risk of precipitation, storage at room temperature, even for extended periods, is recommended. The chemical stability of cisplatin solution also depends on its $\mathrm{pH}$ and the influence of sunlight. The preferable $\mathrm{pH}$ of the solution of proved stability ranges between 3.5 and 5.5 . Cisplatin is also relatively sensitive to light [7].

The purpose of this study was to determine the extended chemical and physical stability of cisplatin in concentrate in glass vials and diluted in polyethylene (PE) bags at normal in-use concentration in saline.

\section{Material and methods}

The research was done at the Department of Clinical Pharmacy and Biopharmacy, Poznan University of Medical Sciences, Poland.

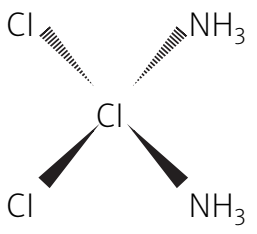

Fig. 1. The chemical structure of cisplatin 


\section{Reagents}

Cisplatin was purchased from LGC Standards (Łomianki, Poland), HPLC grade acetonitrile from Sigma-Aldrich and methanol from Merck. Water used in the mobile phase was deionised, distilled and filtered through a Millipore system before use. Vials containing cisplatin concentrate $1 \mathrm{mg} / \mathrm{ml}$ (batch number 09J29QE) were supplied by Teva Pharmaceuticals Polska, Warsaw, Poland. The $1000 \mathrm{ml}$ polyethylene (Viaflo ${ }^{\circledR}$ ) infusion bags, containing $0.9 \%$ sodium chloride (batch number 10D25E9U), were purchased from Baxter Polska, Warsaw, Poland.

\section{Chromatographic assay method}

The concentration of cisplatin was carried out by means of a high performance liquid chromatographic (HPLC) method with UV detection, which was a modified version of the method developed by M. Pujol Cubells et al. [8]. The high-performance liquid chromatographic (HPLC) system (Alliance, model 2695; Waters Association, Milford, MA, USA) was used with a DAD (Diode Array Detector) (model 2487; Waters Association) and a data acquisition and processing module (Empower Pro Software; Waters Association). Separation was achieved by isocratic elution of the mobile phase, acetonitrile : $\operatorname{water}(90: 10, \mathrm{v} / \mathrm{v}), \mathrm{pH}=9.18$, at a flow rate of $2.0 \mathrm{ml} / \mathrm{min}$ through a Spheriosorb $\mathrm{NH}_{2}$ column $(250 \mathrm{~mm} \times 4.6 \mathrm{~mm}$ I.D., $5 \mu \mathrm{m}$ particle size) (Waters). The column temperature was maintained at $25^{\circ} \mathrm{C}$, the UV-Vis detection wavelength was set at $210 \mathrm{~nm}$, and the injection volume was $50 \mu \mathrm{l}$. The total analysis time for each run was 6 min.

\section{Standard preparation}

Stock solution of cisplatin was prepared from accurately weighed $(24 \mathrm{mg}$ ) pure powder dissolved in water $(10 \mathrm{ml})$. The solution was kept at $4^{\circ} \mathrm{C}$. Working standard solutions were prepared by appropriate dilutions of the stock solution in $0.9 \% \mathrm{NaCl}$ to obtain concentrations across the range of $0.03-1.2 \mathrm{mg} / \mathrm{ml}$. Quality control (QC) samples were prepared freshly on each day of the experiment.

\section{Calibration curve}

The calibration curve was constructed from plots of peak area versus concentration. The linearity of the method was evaluated at seven cisplatin concentrations varying from $0.03 \mathrm{mg} / \mathrm{ml}$ to $1.2 \mathrm{mg} / \mathrm{ml}$ and three-fold injections.

\section{Intra-and inter-day precision and accuracy}

To evaluate the intra- and inter-day accuracy and precision QC standard samples at three concentrations were prepared and determined by quantitating five replicates on the same day and on 3 consecutive days. Table 1 shows intraand inter-day precision (CV\%) and accuracy of this assay method. The precision of the method at each concentration was calculated as the relative standard deviation of the mean (CV) using the following equation:

$$
\mathrm{CV}=(\mathrm{SD} / \text { mean }) \times 100
$$

Accuracy was measured as the percentage difference from theoretical according to the equation:

$$
\begin{aligned}
& \text { Bias }(\%)^{\operatorname{Bi}}=\left(\text { concentration }_{\text {measured }}{ }^{-}\right. \\
& \text {concentration } \left._{\text {theoretical }}\right) /\left(\text { concentration }_{\text {theoretical }}\right) \times 100 \%
\end{aligned}
$$

\section{Limit of detection (LOD) and limit of quantification (LOQ)}

LOD was defined as the analyte concentration giving a signal to noise ratio of $3: 1$. For cisplatin this was $9 \mu \mathrm{g} / \mathrm{ml}$. The LOQ was defined as the analyte concentration giving a signal to noise ratio of $10: 1$. For cisplatin this concentration was $30 \mu \mathrm{g} / \mathrm{ml}$.

\section{Preparation of cisplatin infusions}

All cisplatin infusions were prepared under EU Class A conditions, in accordance with the principles of Good Pharmaceutical Manufacturing Practice. Cisplatin infusions at nominal concentrations of $0.1 \mathrm{mg} / \mathrm{ml}$ were prepared in $0.9 \%$ sodium chloride $(1000 \mathrm{ml})$ in PE bags. Each of the abovementioned infusions was stored, well protected from light, in green polythene overwraps, at room temperature (21.7 $\pm 1.3^{\circ} \mathrm{C}$ ). Samples were analysed immediately after preparation $(t=0)$ and at the following scheduled time intervals: $t=1,2,3,7,14,21,28,30$ days. The concentration of cisplatin in the analysed samples was calculated by using the calibration curve $y=a x+b$.

\section{Visual inspection}

Infusions were visually inspected under standard laboratory lighting against dark and light backgrounds for changes in clarity, colour, and presence of particulate matter.

Table 1. Intra- and inter-day accuracy and precision of cisplatin $(n=5)$

\begin{tabular}{|ccccc}
\hline QC Sample & Concentration $(\mathrm{mg} / \mathrm{ml})$ & Mean SD $(\mathrm{mg} / \mathrm{ml})$ & Accuracy (bias \%) & Precision (CV\%) \\
Intra-day & & & & 3.6 \\
LQC & 0.06 & $0.058 \pm 0.002$ & -3.3 & 3.5 \\
MQC & 0.30 & $0.332 \pm 0.011$ & 10.7 & 2.2 \\
HQC & 0.96 & $1.029 \pm 0.022$ & 7.2 & 5.6 \\
Inter-day & & & & 3.4 \\
LQC & 0.06 & $0.060 \pm 0.003$ & 0.0 & 3.7 \\
MQC & 0.30 & $0.327 \pm 0.011$ & 9.0 & 13.6 \\
HQC & 0.96 & $1.091 \pm 0.040$ &
\end{tabular}

$L Q C$ - low quality control, MQC - medium quality control, $H Q C$ - high quality control 


\section{Results and discussion}

The calibration curve of the peak area versus concentration was found to be linear over the evaluated range from 0.03 to $1.2 \mathrm{mg} / \mathrm{ml}$ in $0.9 \% \mathrm{NaCl}$. The calibration equation was $y=1.61^{*} 10^{4} x+3.54^{*} 10^{5}$. The linear regression coefficient in $0.9 \%$ $\mathrm{NaCl}$ was $r^{2}=0.999$, and linearity was achieved in this range (Fig. 2). Intra- and inter-day precision and accuracy of the LQC $(0.06 \mathrm{mg} / \mathrm{ml})$, MQC $(0.30 \mathrm{mg} / \mathrm{ml})$, and HQC $(0.96 \mathrm{mg} / \mathrm{ml})$ were well within the acceptable limit of $10 \%$ coefficient of variation (CV\%). The results of intra-day precision and accuracy $(n=5)$ are summarized in Table 1. Intra-day precision and inter-day precision were acceptable with all CVs less than $5.6 \%$. The intraday accuracy and inter-day accuracy were also acceptable with the range of $96.7-113.6 \%$. Figure 3A-C shows typical chromatograms obtained from a drug-free solution, concentrate and solution of cisplatin in $0.9 \% \mathrm{NaCl}$, respectively. The chromatograms show that the separation from matrix constituents is sufficient for reliable quantitation and no endogenous components interfered with the analyte peak. The cisplatin peak was detected with retention time of $1.895 \pm 0.027 \mathrm{~min}$.

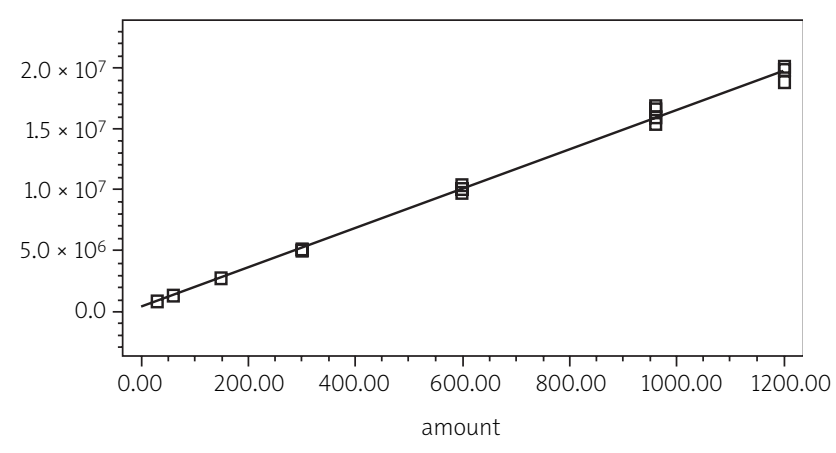

Fig. 2. Standard calibration curves for cisplatin $(n=3)$. Each curve is based on 7 calibration standards with triplicate injections

Tables 2 and 3 list the percentage of intact drug remaining at equilibrium for all cases studied. Cisplatin appears to be stable for at least 30 days in concentrates and in a sodium chloride $0.9 \%$ solution at the concentration of $0.1 \mathrm{mg} / \mathrm{ml}$.

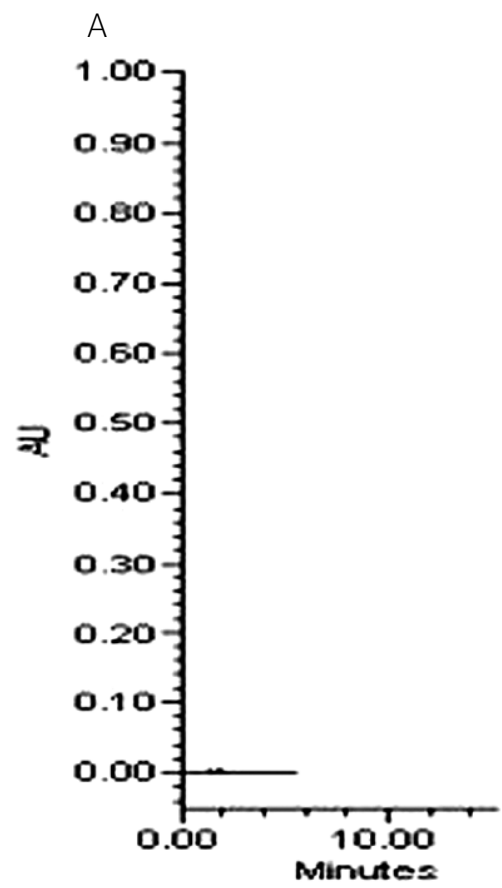

B

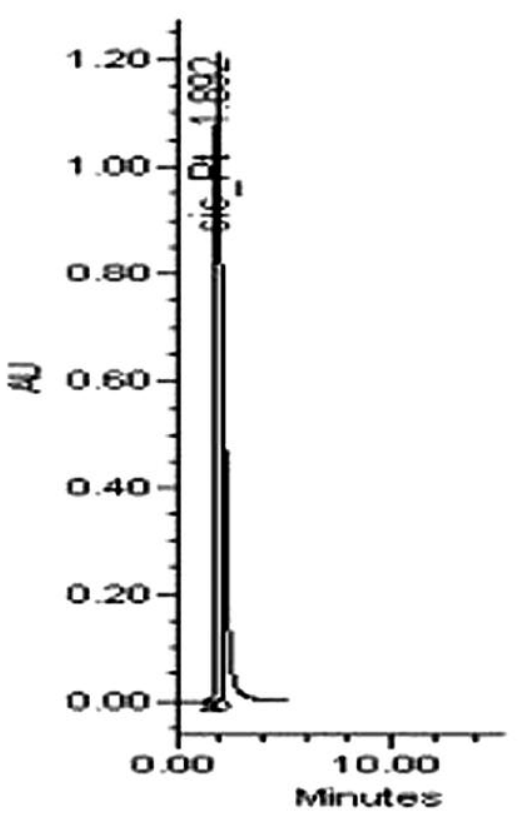

C

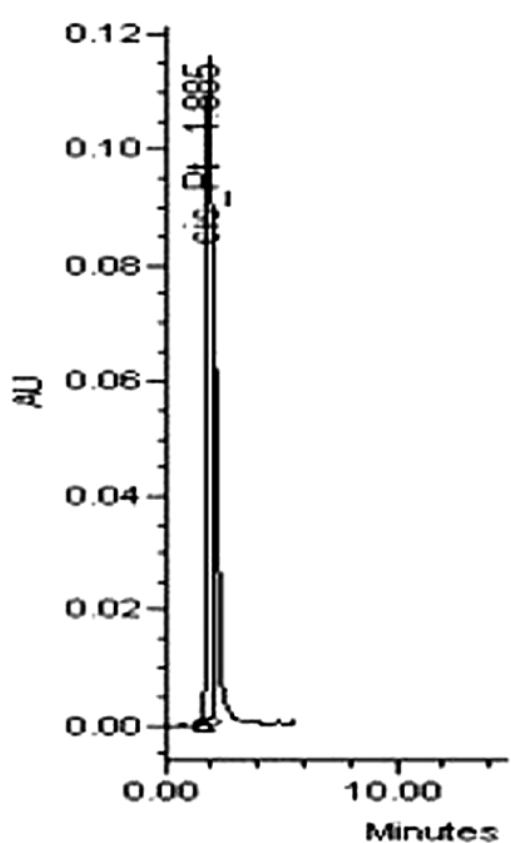

Fig. 3. The chromatogram of cisplatin: a drug-free solution (A), concentrate $-0.976 \mathrm{mg} / \mathrm{ml}$ (B) and solution of cisplatin in $0.9 \%$ $\mathrm{NaCl}-0.095 \mathrm{mg} / \mathrm{ml}(\mathrm{C})$

Table 2. Physical and chemical stability data for cisplatin $(1 \mathrm{mg} / \mathrm{ml})$ in concentrate stored at room temperature $\left(15-25^{\circ} \mathrm{C}\right)$

\begin{tabular}{|c|c|c|c|c|c|c|c|c|c|}
\hline \multirow{2}{*}{$\begin{array}{l}\text { Temperature } \\
15-25^{\circ} \mathrm{C}\end{array}$} & \multicolumn{9}{|c|}{ Percentage of initial concentration at indicated time } \\
\hline & 0 & 1 & 2 & 3 & 7 & 14 & 21 & 28 & 30 \\
\hline Mean & 100.0 & 100.5 & 99.9 & 100.7 & 96.3 & 92.9 & 92.0 & 92.4 & 92.1 \\
\hline SD & 0.0 & 0.03 & 0.006 & 0.03 & 0.03 & 0.003 & 0.01 & 0.01 & 1.6 \\
\hline$n$ & 3 & 3 & 3 & 3 & 3 & 3 & 3 & 3 & 3 \\
\hline $\begin{array}{l}\text { Visual } \\
\text { appearance }\end{array}$ & pass & pass & pass & pass & pass & pass & pass & pass & pass \\
\hline
\end{tabular}


Table 3. Physical and chemical stability data for cisplatin $(0.1 \mathrm{mg} / \mathrm{ml})$ in sodium chloride $0.9 \%$ stored at room temperature $\left(15-25^{\circ} \mathrm{C}\right)$

\begin{tabular}{|c|c|c|c|c|c|c|c|c|c|}
\hline \multirow{2}{*}{$\begin{array}{l}\text { Temperature } \\
15-25^{\circ} \mathrm{C}\end{array}$} & \multicolumn{9}{|c|}{ Percentage of initial concentration at indicated time } \\
\hline & 0 & 1 & 2 & 3 & 7 & 14 & 21 & 28 & 30 \\
\hline Mean & 100.0 & 97.8 & 98.8 & 100.2 & 96.3 & 92.9 & 92.0 & 92.4 & 92.1 \\
\hline SD & 0.0 & 0.02 & 0.02 & 0.02 & 0.03 & 0.02 & 0.03 & 0.02 & 3.6 \\
\hline$n$ & 3 & 3 & 3 & 3 & 3 & 3 & 3 & 3 & 3 \\
\hline $\begin{array}{l}\text { Visual } \\
\text { appearance }\end{array}$ & pass & pass & pass & pass & pass & pass & pass & pass & pass \\
\hline
\end{tabular}

Cisplatin stability was similar both when the solutions were stored in polyethylene bags and in glass containers.

Cisplatin infusion solutions in PE infusion bags are physically stable for at least 30 days. No colour changes and no haze or precipitation were observed in the test solutions during the entire storage period.

Cisplatin in a water solution without $\mathrm{Cl}^{-}$ions rapidly decomposes as a result of the substitution reaction, where one or two chlorine atoms are replaced with a water molecule. In consequence, the drug concentration is reduced by $30-35 \%$ as early as 4 hours afterwards [9]. The presence of $\mathrm{Cl}^{-}$in concentration $>0.2 \%$ has a stabilising effect on the molecule and prevents its decomposition [8,9]. Therefore, cisplatin is administered as an IV infusion after dilution in $0.9 \%$ sodium chloride.

Zieske et al. proved that the $\mathrm{pH}$ value and exposure to shortwave light (350-490 nm) significantly influence the rate of decomposition of cisplatin $(1 \mathrm{mg} / \mathrm{ml})$ stored at the temperature of $22-25^{\circ} \mathrm{C}$ in PVC bags, glass bottles and plastic syringes [10].

Hrubigkol et al. analysed cisplatin solutions in concentrations of 1.0 and $1.6 \mathrm{mg} / \mathrm{ml}$ placed in plastic infusion bags for 14 days and did not observe the influence of temperature on the rate of drug decomposition. However, increased concentrations of cisplatin in the solutions were observed, which grew along with higher temperature $\left(25^{\circ} \mathrm{C}<1 \%, 37^{\circ} \mathrm{C}\right.$ $\left.<3 \%, 60^{\circ} \mathrm{C}-8.2 \%\right)$. The phenomenon was most likely to have been caused by evaporation of the solvent [11]. On the other hand, Mitter et al. proved the significant influence of temperature on the drug stability. For the solution in a concentration of $0.1 \mathrm{mg} / \mathrm{ml}$ stored at room temperature for 7 days the loss of the drug was higher $(84.5 \pm 1.5 \%)$ than for solutions stored in the refrigerator $(97.4 \pm 0.9 \%)$ [12].

Cisplatin does not exhibit interaction with the materials from which the drug packages, infusion bags or other elements in contact with the cytostatic are made [13]. Pujol et al. analysed a solution in a concentration of $0.166 \mathrm{mg} / \mathrm{ml}$, which was protected from light and stored at the temperature of $30^{\circ} \mathrm{C}$. The analysis confirmed its stability for 14 days in all storage containers: glass bottles $(99.7 \pm 0.3 \%)$, PVC bags (104.6 $\pm 1.0 \%)$, polyethylene bags $(98.9 \pm 1.0 \%)$ and polypropylene bags $(100.1 \pm 0.5 \%)$ [13]. Rochard et al. proved the stability of cisplatin in concentrations of 0.5 and $0.9 \mathrm{mg} / \mathrm{ml}$, which was placed in ambulatory infusion pumps made from ethylene-vinyl acetate and stored at the temperature of $22^{\circ} \mathrm{C}$ and $35^{\circ} \mathrm{C}$ for 28 days [14]. Swell [7] points to the stability of Teva cisplatin solution diluted to the concentrations of 0.1 and $0.4 \mathrm{mg} / \mathrm{ml}$ with a $0.9 \% \mathrm{NaCl}$ solution, placed in PVC bags and stored at the temperature of $25^{\circ} \mathrm{C}$ without access to light for 28 days. Longer storage of the solution involved the potential risk of precipitation, traces of which could be observed after 35 days.

In our own research we analysed the drug in a concentration of $1 \mathrm{mg} / \mathrm{ml}$ and volume of $50 \mathrm{ml}$ after opening of the original glass vial, which was stored in a hospital pharmacy at the temperature of $21.7 \pm 1.3^{\circ} \mathrm{C}$ without access to light. The concentration was measured immediately on opening of the preparation and after $24 \mathrm{~h}, 48 \mathrm{~h}, 72 \mathrm{~h}, 6,7,8,9,10$, $13,14,15,21,28,30$ days. On the 10th day the average change in the concentration was $95.06 \%$, as compared with the concentration measured immediately on opening, whereas 30 days after opening it was $92.09 \%$ (Table 2). A cisplatin solution in a concentration of $0.1 \mathrm{mg} / \mathrm{ml}$ was also analysed. The solution was prepared by adding a concentrate of $1 \mathrm{mg} / \mathrm{ml}$ to a $0.9 \% \mathrm{NaCl}$ solution and storing at the temperature of $21.7 \pm 1.3^{\circ} \mathrm{C}$ without access to light. Samples for measurements of concentrations and determination of percentage change were collected at the same time intervals as for the concentrate. After 30 days the average change in the concentration of the solution was $93.90 \%$ (Table 3). A smaller loss of cisplatin in solutions diluted with $0.9 \% \mathrm{NaCl}$ may indicate the stabilising effect of the solvent.

The confirmation of long-term stability involves the possibility to prepare drugs in advance for the whole weekend or even for the whole period of therapy without the involvement of nursing staff in the process [15]. The aim of this action is to reduce the workload and optimal time management by pharmacists employed in cytostatic laboratories [16, 17].

In conclusion, cisplatin appears to be physically and chemically stable for at least 30 days in concentrate in glass containers or diluted with $0.9 \%$ sodium chloride in $\mathrm{PE}$ bags at a concentration of $10 \mathrm{mg} / \mathrm{ml}$, at room temperature $\left(15-25^{\circ} \mathrm{C}\right)$ when protected from light.

\section{Disclosure of financial interest}

This study was supported with an educational grant from Teva Poland.

The authors: A. Karbownik, E. Szatek declare conflict of interest. 


\section{References}

1. Hanigan MH, Devarajan P. Cisplatin nephrotoxicity: molecular mechanisms. Cancer Ther 2003; 1: 47-61

2. Piulats JM, Jiménez L, García del Muro X, Villanueva A, Viñals F, Germà-Lluch JR. Molecular mechanism behind the resistance of cisplatin in germ cell tumours. Clin Transl Oncol 2009; 11: 780-6.

3. Miller RP, Tadagavadi RK, Ramesh G, Reeves WB. Mechanisms of Cisplatin nephrotoxicity. Toxins (Basel) 2010; 2: 2490-518.

4. Baskerville-Abraham IM, Boysen G, Troutman JM, et al. Development of an ultraperformance liquid chromatography/mass spectrometry method to quantify cisplatin 1,2 intrastrand guanine-guanine adducts. Chem Res Toxicol 2009; 22: 905-12.

5. Cepeda V, Fuertes MA, Castilla J, Alonso C, Quevedo C, Pérez JM. Biochemical mechanisms of cisplatin cytotoxicity. Anticancer Agents Med Chem 2007; 7: 3-18.

6. Gonzalez VM, Fuertes MA, Alonso C, Perez JM. Is cisplatin-induced cell death always produced by apoptosis? Mol Pharmacol 2001; 59: 657-63.

7. Sewell G. Physical and chemical stability of cisplatin infusions in PVC containers. EJOP 2010; 4: 11-3.

8. Pujol Cubells M, Prat Aixela J, Girona Brumos V, Duran Pou S, Villaronga Flaque M. Stability of cisplatin in sodium chloride $0.9 \%$ intravenous solution related to the container's material. Pharm World Sci 1993; 15: 34-6.

9. Allwood M, Stanley A, Wright P. The cytotoxics handbook. Radcliffe Publishing, Abingdon 2002; 286-9, 414-6, 426-7.

10. Zieske PA, Koberda M, Hines JL, Knight CC, Sriram R, Raghavan NV, Rabinow BE. Characterization of cisplatin degradation as affected by pH and light. Am J Hosp Pharm 1991; 48: 1500-6.

11. Hrubisko M, Mc Gown AT, Prendiville JA, Radford JA, Thatcher N, Fox BW. Suitability of cisplatin solutions for 14-day continuous infusion by ambulatory pump. Cancer Chemother Pharmacol 1992; 29: 252-5.

12. Mittner A, Vincze Z, Jemnitz K. Stability of cisplatin containing infu sion. Pharmazie 1998; 53: 490-2.

13. Pujol Cubells M, Prat Aixela J, Girona Brumos V, Duran Pou S, Villaronga Flaque M. Stability of cisplatin in sodium chloride $0.9 \%$ intra venous solution related to the container's material. Pharm World Sci 1993; 15: 34-6.

14. Rochard E, Barthes D, Courtois P. Stability of cisplatin in ethylene vinylacetate portable infusion-pump reservoirs. J Clin Pharm Ther 1992; 17: 315-8.

15. Lecompte D, Bousselet M, Gayrard D, Poitou P. Stability study of re constituted and diluted solutions of calcium folinate. Pharm Ind 1991 53: 90-4.

16. Astier A, Pinguet F, Vigneron J. The practical stability of anticancer drugs: SFPO and ESOP recommendations. EJOP 2010; 4: 4-6.

17. Bardin C, Astier A, Vulto A, et al. Guidelines for the practical stability studies of anticancer drugs: a European consensus conference. Ann Pharm Fr 2011; 69: 221-31.

\section{Address for correspondence}

\section{dr n. farm. Agnieszka Karbownik}

Katedra i Zakład Farmacji Klinicznej i Biofarmacji

Uniwersytet Medyczny w Poznaniu

ul. św. Marii Magdaleny 14

61-861 Poznań

tel./fax +48616687837

e-mail: aganieszkakarbownik@o2.pl

Submitted: 14.11.2011

Accepted: $\quad 21.06 .2012$ 